UDC 14.01.22

DOI: 10.32345/USMYJ.3(111).2019.54-63

\title{
Шпачинський Олександр
}

Хірург-стоматолог СМЦ НМУ імені О.О. Богомольця, Україна

\section{Скібіцький Вадим}

К.мед.н, доцент кафедри ортопедичної стоматології НМУ імені О.О. Богомольця, Україна Філіппенкова Лариса

К.мед.н., доцент кафедри ортопедичної стоматології та ортодонтії ПВНЗ КМУ, Україна

Василевський Костянтин

Лікар- рентгенолог СМЦ НМУ імені О.О. Богомольця, Україна

\section{Дідковський В'ячеслав}

К.мед.н, доцент кафедри оториноларингології НМУ імені О.О. Богомольця, Україна

Копчак Андрій

Д.мед.н., професор кафедри стоматології інституту післядипломної освіти

НМУ імені О.О. Богомольця, Україна

\section{ТОМОГРАФІЧНЕ ДОСЛІДЖЕННЯ ЗМІН МУКОПЕРІОСТУ ВЕРХНЬОЩЕЛЕПНОЇ ПАЗУХИ ПІСЛЯ ПРОВЕДЕННЯ СИНУСЛІФТИНГУ}

\begin{abstract}
Анотація. Відновлення жувальної ефективності у пацієнтів з дистаотно необмеженими дебектами зубного ряду верхньої щедепи, з опорою дентальних протезів на імплантах, часто є складним завданням через значну атрофію альвеолярного відростку та пневматизацію верхньощелепного синусу. Відновлення жувальної функиї в таких ситуаціях можливе за якісної оцінки стану кісткової тканини, прилеглих анатомічних структур, стану мукоперіосту верхньощелепного синусу, на основі конусно-променевої комп'ютерної томографії (КПКТ) та проведення латеральної субантральної аугментації (ЛСАА).

Процедура (ЛСАА) проведена на базі Стоматологічного медичного иентру НМУ імені О.О. Богомольия за згодою 87 пацієнтів, з 2016 по 2018 роки.

Всім пацієнтам проводилась КПКТ на доопераційному етапі, а також в період 1 та 6 місяців після проведення ЛСАА. Проведення та оцінка даних здійснювалась на апараmi Planmeca ProMax 3D. Дані КПКТ демонструють падіння показників мукоперіосту типу $A$ з 86,67 до 26,75\%. Кількість випадків тип В незначно збільшились з 20,33\% до 26,75 \%. Показники мукоперіосту наступні, 7,5 проти 41,73\%. Типи D та Е в межах 13.91 та 2.14\% Однак, ознаки гострого синуситу констатуються тільки в 2 випадках. В 3 випадках рентгенологічно фіксувався тип F. Підсумовуючи, незначні зміни мукоперіосту спостерігались у 17.12\% пацієнтів, яким проведено ЛСАА. Оскільки оцінка та діагностика змін мукоперіосту на осноі клінічних та рентгенологічних даних є складними - ие доводить необхідність мультидисииплвнарного підходу, участі ЛОР-лікарів та ендоскопічного контролю пацієнтів, яким проведиться процедура ЛСАА.
\end{abstract}

Ключові слова: латеральна субантральна аугментація, синусліфтинг, конусно-променева комп’ютерна томографія, мукоперіост, синусит.

Cite as: Shpachynskyi O., Skibitskyi V., Filippenkova L., Vasilevskyi K., Didkovskyi V., Kopchak A. Tomographic examination of changes in mucoperiost of the maxillary sinus after sinus lifting

Ukrainian scientific medical youth journal, issue, 4(112), $2019 \quad$ DOI: 10.32345/USMYJ.3(111).2019.54-63 
Вступ. Розміщення імплантатів у дистальних відділах верхньої щелепи часто виявляється неможливим, або утрудненим через недостатню кісткову пропозицію (зменшення об’єму та зниження якості кісткової тканини альвеолярного відростку після видалення зубів). Стандартним методом передімплантаційної підготовки, що дозволяє створити необхідний для встановлення імплантатів об’єм кісткової тканини $є$ латеральна субантральна аугментація (ЛСАА) або синусліфтинг. Техніка ЛСАА була запропонована Tatum в 1977 році і після модифікації Boyne and James в 1980, набула широкого розповсюдження (Boyne P., James R.A., 1980; Chanavaz M., 1979; Choucroun G. et al., 2017). ЛСАА полягає у проведенні остіотомії передньої стінки верхньощелепного синусу, на ділянці майбутньої імплантації, відшаруванні мукоперіосту без порушення його цілісності та внесенні у штучно створений простір кісткозаміщуючого матеріалу. Для цього використовують такі матеріали як: аутологічна кістка (Smiler D.G., Holmes R.E., 1987; Tatum Н., 1986), демінералізований кістковий матрикс (Ritter A. et al., 2019), синтетичний гідроксиапатит (Giovanni Felisati et al., 2013; Horia Mihail Barbu et al., 2019), бета-трикальцій-фосфат або біокераміка. За даними авторів синусліфтинг - відносно безпечна i прогнозована процедура для відновлення об’єму альвеолярного відростка (Sbordone C. et al., 2014).

Разом $з$ тим, ряд дослідженнь повідомляють про ускладнення пов'язані з даною процедурою. Найбільш поширеними серед них є: перфорація слизової оболонки верхньощелепного синусу (Daiane Balero Galindo et al., 2017; Torrade M., Marti C., 2008), нагноєння операційної рани та інфікування кістково-заміщуючого матеріалу, дизосмія та формування хронічного синуситу (Akram Mahmood Elias B. D., 2009). Останнє ускладнення найбільш не- сприятливе: воно часто потребує додаткових хірургічних маніпуляцій для ліквідації патологічного процесу, подовжує період реабілітації, нерідко, унеможливлює встановлення дентальних імплантатів.

За даними літератури гострий синусит після проведення синусліфтингу виникає в 10-26\% (Demircol M., Demircol N., 2019; Erhan Dursun et al., 2019; Minhua Teng et al., 2016; Rapani M. et al., 2016). Частота хронічного синуситу, пов'язаного із проведеною ЛСАА $€$ меншою і становить 1,3-5\% (Cavalcanti MC et al., 2018, Daiane Balero Galindo et al., 2017; Sanz-Sánchez I et al., 2018; Stefano Corbella et al., 2016). Разом 3 тим, кількість досліджень, присвячених змінам слизової оболонки верхньощелепного синусу, що виникають після проведення синусліфтингу вкрай обмежена, їх результати суперечливі, і зазвичай обмежені раннім післяопераційним періодом. Механізми виникнення синуситу після проведення ЛСАА вивчені недостатньо і роль ятрогенного впливу при цьому визначена не до кінця.

Аналіз літературних джерел свідчить, що частота виражених морфологічних та рентгенологічних змін мукоперіосту верхньощелепного синуса може бути більшою ніж частота клінічно діагностованого верхньощелепного синуситу, оскільки у багатьох пацієнтів ці зміни розвиваються безсимптомно і тривалий час не викликають жодних скарг. Питання ранньої діагностики морфологічних змін, визначення їх природи і оптимальної лікувальної тактики, а також можливості встановлення дентальних імплантатів в цих випадках залишаються не вирішеними.

При проведенні ЛСАА, перед хірургом завжди постає питання: в який спосіб проводити втручання не пошкодивши анатомію мукоперіосту, та як зберегти функцію та запобігти ускладнень, особливо у випадках коли стан слизової болонки верхньощелепного синуса скомпромето- 
ваний внаслідок раніше перенесених чи наявних патологічних процесів, операцій і травм.

Метою даного ретроспективного дослідження було - вивчити рентгенологічні прояви морфологічних змін мукоперіосту верхньощелепного синусу на основі КЛКТ до та після проведення операцій синусліфтингу (ЛСАА), а також оцінити частоту післяопераційних ускладнень та визначити фактори ризику їх виникнення.

Методологія та методи дослідження. Матеріалом даного клініко-лабораторного дослідження були пацієнти, яким було виконано синусліфтинг (ЛСАА) за традиційною методикою на базі Стоматологічного медичного центру НМУ імені О.О. Богомольця та Центру щелепно-лицьової хірургії Київської обласної клінічної лікарні.

В дослідження включали пацієнтів 3 ділянками адентії в дистальних відділах верхньої щелепи та залишковою висотою альвеолярного відростка (ЗВАВ) менше 5 мм, яким проводили процедуру одночи двостороннього синусліфтингу із використанням латерального доступу відповідно до протоколів ITI (International Team for Implantology) та виконували КПКТ в до та післяопераційному періоді та перед встановленням імплантатів.

Критеріями виключення були: вік до 18 років, період від видалення зуба в ділянці втручання менше 4 місяців, променева або хіміотерапія, злоякісні новоутворення в анамнезі, зловживання наркотичними засобами, агресивні форми пародонтиту, системні захворювання в декомпенсованій або субкомпенсованій формах, остеопороз, присутність рентгенологічних ознак гострого чи хронічного синуситу, відмова пацієнта від участі у дослідженні.

Критеріям дослідження відповідало 87 пацієнтів (50 жінок та 37 чоловіків), віком від 20 до 63 років (середній вік склав $32+14,2$ роки). Односторонній синусліфтинг був проведений 67 пацієнтам, двосторонній 20 пацієнтам. Загалом було проведено 107 операцій синусліфтингу - 60 (56\%) з них на лівій пазусі, 47 (44\%) на правій. В ділянки аугментації пацієнта було встановлено загалом 183 дентальні імплантати: 3 них 38 за протоколом одномоментної імплантації та 145 за протоколом відтермінованої двоетапної імплантації. Для імплантації використовували традиційні конусні остеоінтегруючі імплантати системи MIS (MedicalImplantSystem, MI SImplantTechnologiesLtd,Shlomi, Israel), MegaGen (MegaGen, Gyeongsan, Daegu, SouthKorea), B.\&B. Dental s.r.l, Italy та Straumann (StraumannHoldingAG, Switzerland). Діаметр та довжина дентальних імплантів варіювали від 3.0 до 5.0 мм та від 7.5 до 13 мм відповідно.

Клінічні та рентгенологічні відомості про пацієнтів були систематизовані в наступних категоріях: загальний стан здоров'я, хронологія діагностичних та контрольних КПКТ, що відображає якість та об'єм маніпуляції ЛСАА, стоматологічний та пародонтологічний статус, ЛОРанамнез, куріння, тип застосованого кістково-заміщуючого матеріалу, протокол встановлення імплантатів. КПКТ проводили всім пацієнтам перед операцією 3 метою оцінки: ЗВАВ, морфології носової порожнини та придаткових пазух носа; в ранньому післяопераційному періоді (до 1 місяця) та у віддаленому періоді (6 місяців) для оцінки морфологічних змін мукоперіосту верхньощелепного синусу в динаміці.

Всім пацієнтам проведена стандартна процедура ЛСАА. Після антисептичної обробки ротової порожнини водним розчином хлоргексидину, проводили місцеву анестезію 4\% розчином артикаїну з адреналіном 1:200000 (Ubistesin, 3 M-Espe, StPaul, MN, USA). Загальну ане- 
стезію проведена 5 пацієнтам, у яких реконструкція альвеолярного відростка передбачала застосування аутологічних кісткових трансплантатів із гребеня клубової кістки. Після проведення трапецієподібного розтину слизової оболонки альвеолярного відростка, і відшарування слизо-окістного клаптя, проводили остіотомію передньої стінки верхньощелепного синуса круглим бором з алмазним напиленням під охолодженням. Після оголення мукоперіосту, останній відшаровували в усіх напрямках за допомогою ложок для синусліфтингу. Штучно створений простір заповнювали кістково-заміщуючим матеріалом. При перфорації мукоперіосту невеликого розміру (до 5 мм в діаметрі), мембрану ушивали полігліколідом 6.0, або перекривали колагеновою (Bio-Gide, GeistlichBiomaterials, Wolhusen,Switzerland, or BioMed ${ }^{\circledR}$ Zimmer Biomet, Munich, Germany) чи аутологічною фібриновою мембраною (PRGF, PRF). У разі отримання перфорації, що перевищувала 5 мм в діаметрі, процедуру зупиняли і відтерміновували на 2 місяці.

Для проведення субантральної аугментації використовували наступні кістково-заміщуючі матеріали: АВКТ з гребеня клубової кістки - 5,7 \%, ксеногенні трансплантати (Cerabone, Botissbiomaterials $\mathrm{GmbH}$, Gerlingen, Germanyor GenOs, Osteobiol, TecnossDental, Torino, Italy) (TutogenMedicalGmbH ${ }^{\mathrm{mm}} \quad 0.25-1.0$ mmor 1-2 mm; Germany) - 85,2\% та суміш ксеногенного матеріалу із аутологічною кісткою - 9,1\%.

Всі пацієнти були попереджені про наслідки хірургічного втручання та отримали відповідні рекомендації. Нікотинозалежні пацієнти були попереджені про підвищений ризик ускладнень та проінформовані про необхідність відмови від паління. В післяопераційному періоді всім пацієнтам було рекомендовано проводити ротові ванночки розчином хлоргексидину 0,12\%. Призначено антибіотикопрофілактику - кліндаміцин 300 мг перорально 3 рази на день або амоксицилін/амоксиклав 500 мг 2 раз на день. Нестероїдні протизапальні препарати призначені на 5-7 днів. Шви знімали на 10-14 день після операції

Всім пацієнтам КПКТ проводилось на апараті PlanmecaProMax 3D. Параметри сканування були наступні: $120 \mathrm{kVp}, 5$ мА, 0.3 мм товщина аксіального зрізу, і $20 \times$ 17 см - розмір вимірюваної ділянки. Всі дані були представлені у форматі Digital Imaging and Communications in Medicine format (DICOM). В подальшому отримані файли аналізували у програмному середовищі SimPlantPro 11.04 (Materialize, Бельгия). Лікарем-рентгенологом, хірургом-стоматологом та оториноларингологом було інтерпретовано морфологічні зміни та анатомічні особливості кожного пацієнта до та після операції. На основі отриманих рентгенологічних показників пацієнти розподілені на 6 груп відповідно класифікації Chen et al. (групи від А до F): A) неспецифічні зміни, B) поодинокий поліп чи кіста, C) потовщення мукоперіосту, D) накопичення рідини з чітким рівнем (показник гострого інфекційного запального процесу або наявність гемосинусу), Е) субтотальне затемнення (найчастіше характерне для хронічного синуситу), і F) стороннє рентгенконтрастне тіло (найчастіше відповідало пенетрації кістковозаміщуючого матеріалу після ЛСАА, або міцетомі) (Yi-Wei Chen et al., 2018). (Мал. 1)

Результати. Аналіз даних КПКТ, проведеного передопераційно виявив, що 66 (75,8\%) пацієнтів мали нормальну анатомію верхньощелепного синусу без специфічних змін з боку мукоперіосту - тип А; 15(17,3\%) пацієнтів мали тип B; тип С був наявний у $6(6,9 \%)$ пацієнтів. Зміни слизової оболонки за типами $\mathrm{D}, \mathrm{E}, \mathrm{F}$ не відзначали (такий стан синусу розглядали, 
як протипоказання до ЛСАА). Серед всіх пацієнтів 16 (18\%) систематично палили, 8.7\% пацієнтів перенесли операції на верньощелепному синусі в анамнезі або мали хронічні захворювання ЛОР органів.

Індивідуальні анатомічні особливості архітектоніки верхньощелепного синусу визначали за класифікацією Al-Faraje (Khalighi Sigaroudi A. et al., 2017): 72 синуси (67.2\%) - не мали септ, 35 мали різні типи септ, що асоційовані із тим чи іншим ризиком перфорації муко періосту на етапі відшарування. У 22 (20.5\%) - тип 1 (поодинока септа, що орієнтована перпендикулярно до дна верхньощелепного синусу-низький ризик перфораціі), 3 $(2,8 \%)$ - тип 2 (множинні септи (2 та більше), що орієнтовані перпендикулярно до дна верхньощелепного синусу - низький ризик перфораціі), 3 (2.8\%) - тип 3 (поодинока довга септа, що орієнтована перпендикулярно та не обмежено в основі дном верхньощелепного синусу - опосередкований ризик перфорації), 4 (3.7\%) - тип 4 (множинні септи, що орієнтовані перпендикулярно та не обмежені в основі дном верхньощелепного синусу-високий ризик перфораціі), 3 (2,8\%) - тип 5 (часткова горизонтальна септа - низький ризик перфораціі). (16).(Мал. 2)

Показник ЗВАВ у пацієнтів був наступним: $<1$ мм - 19 випадків (17.7 \%), 1-2 мм в 45 випадках (42\%), 2-3 мм в 33 випадках (30.8 \%), 3-5 мм - 10 випадків (9.2\%). Середній показник ЗВАВ склав 2.36+0,9 мм. ЗВАВ вірогідно залежала від часу 3 видалення зуба $(\mathrm{p}<0.05)$. У пацієнтів із ЗВАВ <1 мм середній термін від видалення склав $14.3+2,1$ років, $1-3$ мм $-12.8+1,7$ років, 3-5 мм - 5,5+1,1 років. (Мал. 4$)$

За даними КПКТ, яку було проведено в ранні строки (до 1 місяця після операціі) кількість пацієнтів із інтактним синусом типу А знизилась з 86,67 до 26,75 \%. Кількість випадків типу В збільшилась 3 $20,33 \%$ до 26,75\%. Потовщення мукопері- осту типу С було відзначено у 7,5\% проти $41,73 \%$. Тип D та Е становили $13.91 \%$ і 2.14\% відповідно (до операції такі типи змін слизової оболонки не відзначали). При цьому клінічні прояви синуситу і відповідні скарги були наявні лише у 2 хворих. В 3 випадках (2,8\%) рентгенологічні ознаки нагадували тип F і були пов'язані з інфікуванням кітково-заміщуючого матеріалу та міграцією частинок кісткового матеріалу до порожнини верхньощелепного синусу.

Через 6 місяців після ЛСАА рентгенологічний статус покращився у 42 (48,8\%) пацієнтів. Кількість випадків, що відповідали типу А та В зросла до 57,78\% та 37,45\% відповідно. Натомість, кількість випадків з ознаками змін типу C та D знизилась: до 11,77 та 5,35 \% відповідно. В 2 випадках за даними КПКТ виявили зміни, що відповідали типу Е. Їх розглядали, як показання до реоперації та санації верхньощелепного синусу. (Мал. 3)

Кореляційний аналіз не виявив статистично вірогідних залежностей між рентгенологічними змінами морфології мукоперіосту верхньощелепного синусу на всіх етапах рентгенологічного контролю та ЗВАВ, видом застосованого кістково-заміщуючого матеріалу, архітектонікою синуса та типом септ, а також наявними у пацієнта шкідливими звичками.

Із загальної кількості досліджуваних, у 12 пацієнтів інтраопераційно або в постопераційному періоді розвинулись ускладнення: перфорація мукоперіосту (зустрічалась найчастіше) - 12 випадків (11.2\%), інтенсивна кровотеча - 5 випадків (5,7\%), міграція кістково-заміщуючого матеріалу до верхньощелепного синусу - 3 випадки $(2,8 \%)$, розвиток хронічного синуситу.

Серед встановлених 183 дентальних імплантатів до моменту встановлення постійної ортопедичної конструкції дезінтегрувалось 18 (9\%). Статистичної залежності між дезінтеграцією імплантатів та 
рентгенологічними змінами морфології мукоперіосту верхньощелепного синусу виявлено не було.

Дискусія. За даними літератури ЛССА $є$ поширеним методом передімплантаційної підготовки, що характеризується високим рівнем ефективності і прогнозованості. Водночас, кількість випадків пов'язаних $з$ розвитком запальних процесів у верхньощелепному синусі та порушенням його функції після ЛСАА залишається високою. За даними ретроспективного дослідження в 12\% випадків синусліфтинг пов'язаний із розвитком хронічного риносинуситу в післяопераційному періоді (Khalighi Sigaroudi A. et al., 2017). За даними інших авторів цей показник навіть вищий - від 19 до $22 \%$. Автори висловлюють припущення, що основними чинниками, які впливають на найближчий і віддалений прогноз синусліфтингу є вихідний стан мукоперіосту та остіомеатального комплексу (ОМК), техніка остіотомії, об'єм та тип кістковозаміщуючого матеріалу тощо. За даними (Khalighi Sigaroudi A. et al., 2017) операції, що проводились на скомпрометованому верхньощелепному синусі із ознаками ЛОР-патологієї, або ускладненою архітектонікою (наявність септи верхньощелепної пазухи, нерівності чи поглиблення дна пазухи) були пов'язані з вищим ризиком перфорації мукоперіосту та післяопераційних ускладнень.

За нашими даними рентгенологічно зміни мукоперіосту (тип В і С) відзначали у $27,3 \%$ пацієнтів, а септи були наявні у $32.7 \%$, в тому числі - несприятливі у $6,5 \%$. Зміни стану муко періосту відзначали у більшості хворих (в 68.48 \%) з них 19.26 \% мали несприятливі типи D, E, F (Yi-Wei Chen et al., 2018). На 6 місяць локальні і дифузні потовщення слизової оболонки зустрічали в $46,6 \%$, водночас в абсолютній більшості випадків ці зміни протікали безсимптомно і не викликали жодних скарг чи дискомфорту пацієнтів.
Головним обмеженням даного дослідження стала відсутність ендоскопічного контролю, що унеможливило диференціацію отриманих на основі КПКТ рентгенологічних даних, які у відриві від клінічних чи ендоскопічних даних можуть інтерпретуватись невірно, призвести до гіпердіагностики, більш агресивної лікувальної тактики або необгрунтованої відмови від встановлення дентальних імплантатів.

В нашому дослідженні не було виявлено вірогідних кореляцій між станом мукоперіосту в доопераційному періоді та ризиком перфорації, запальних ускладнень та виразності післяопераційних змін мукоперіосту. ЗВАВ, наявність септ та тип застосованих кістково-заміщуючих матеріалів також не впливали на стан мукоперіосту у віддаленому післяопераційному періоді. Це свідчить, що виникнення ускладнень та морфологічних змін в верхньощелепному синусі може залежати більшою мірою від риногенних чинників: стану остіомеатального комплексу, субкомпенсованих порушень муко-циліарного кліренсу та ін. Отримані данні таким чином свідчать про необхідність комплексного передопераційного обстеження хворих із консультацією ЛОР-лікаря і відео ендоскопією синуса за наявних показань. В роботах (Sonoda T. et al., 2019; Yi-Wei Chen et al., 2018; Zeng X. et al., 2016) зазначається, що локальні (до 17 мм в діаметрі) та дифузні (не більше 5 мм) потовщення мукопереіосту після перенесених захворювань та хірургічних втручань не $\epsilon$ протипоказанням до проведення синусліфтингу. Отримані нами дані підтверджують думку авторів із зауваженням, що в будь-яких сумнівних випадках природа рентгенологічних змін мукоперіоста верхньощелепного синусу має бути верифікована методом ендоскопії. В післяопераційному періоді ендоскопічний контроль $€$ незамінним інструментом в 
диференційній діагностиці хронічного синуситу від післяопераційних змін слизової оболонки, що можуть піддаватись зворотному розвитку без застосування радикального хірургічного підходу, а також в значній частині випадків мініінвазивно ліквідувати ускладнення, такі як міграція матеріалу в порожнину синуca, блокада остіомеатального комплексу тощо.

В даному дослідженні також було проаналізовано всі випадки перфорації мукоперіосту. Дане ускладнення добре описано в літературі і за даними авторів становить від 11.2-20\% (Cruz RS et al., 2018; Silva L.D. et al., 2016), а за нашими даними - 12\%. Зважаючи на незначну кількість хворих із перфорацією ми не змогли виявити сатистично значущих кореляцій між ризиком перфорації і наявністю перетинок в синусі, ЗВАВ та палінням в анамнезі, на що вказують дослідження (Al-Dajani M., 2014; Hoang JK et al., 2010; Kim SM., 2019). При цьому, перфорації, що були ефективно усунені в ході оперативного втручання, за нашими даними не асоціювалась 3 підвищеним рівнем гнійно-інфекційних ускладнень та дезінтеграції імплантатів. Однак в усіх випадках, це були малі перфорації до 5 мм, (при великих перфораціях, субантральну аугментацію не проводили, а пацієнти були виключені з досліджуваної групи).

Всі імплантати, що були встановлені безпосередньо чи відтерміновано на ділянці субантаральної аугментації мали достатню первинну стабільність, а рівень ï відторгнення (9\%) знаходився в межах визначених для нативного альвеолярного відростку верхньої щелепи і вірогідно не залежав від виразності морфологічних змін мукоперіоста у до та післяопераційному періоді.

Висновки. Встановлено, що незначні зміни морфології мукоперіосту верхньощелепного синусу за даними КПКТ спо- стерігали передопераційно 75,8\% пацієнтів, яким проводили ЛСАА. Випадки інфікування кістковозаміщуючого метеріалу, гострого чи хронічного синуситу в післяопераційному періоді відзначали у 19.26 \%. Натомість, зміни слизової верхньощеоепного синусу із безсимптомним перебігом виникали значно частіше: 68,48 $\%$ в ранньому (до 1 місяця) і 47,1 \% у віддаленому (6 місяців) післяопераційному періоді. Оскільки диференційна діагностика таких змін, на основі лише клінічних та рентгенологічних даних $є$ утрудненою, отримані результати свідчать про важливість передопераційного ендоскопічного обстеження, інтра- та постопераційного контролю пацієнтів, яким проводять ЛСАА, а також переваги мультидисциплінарного підходу у плануванні даної маніпуляції, підходів до ведення пацієнтів, своєчасного усунення ускладнень та їх післяопераційної реабілітаціі.

\section{Авторські внески:}

Шпачинський O.C.

Оцінка клінічного стану пацієнтів на доопераційному етапі. Безпосереднє проведення маніпуляцій латеральної субантральної аугментації, імплантації та післяопераційне ведення пацієнтів. Інтерпретація рентгенологічних даних отриманих на основі КПКТ в програмному забезпеченні SimPlantPro 11.04 (Materialize, Бельгия)

Скібіцьький В.С.

Підготовка пацієнтів до імплантації. Планування реабілітації пацієнтів. Протезування на імплантатах тимчасовими та постійними ортопедичними конструкціями.

Філіппенкова Л.О.

Реабілітація пацієнтів тимчасовими ортопедичними іммедіат протезними конструкціями на ранньому післяопераційному періоді. Безпосереднє протезування на імплантатах постійними ортопедичними конструкціями. 


\section{Василевський К.I. \\ Інтерпретація рентгенологічних даних отриманих на основі КПКТ. \\ Дідковський В.Л. \\ Ендоскопічний контроль пацієнтів, які потребували консультації та втручання суміжного спеціаліста. Проведення мі- \\ кроінвазивної гайморотомії, відновлення дренажної функції верхньощелепного си- нусу через остіомінатальний комплекс. \\ Копчак А.B. \\ Курація, огляд та редагування отри- маних результатів. Контроль методології дослідження.}

\section{ЛІТЕРАТУРА}

Akram Mahmood Elias B. D. Supervised By Assistant Professor DR. Luqman Fawzi Omar B.D.S, M.Sc. (2009) Maxillary sinus membrane elevation and simultaneous implant placement without grafting materials.J. Clinical and Radiographical Study 16: 11-13.

Al-Dajani M. Recent Trends in Sinus Lift Surgery and Their Clinical Implications. Clin Implant Dent Relat Res. 2016 Feb;18(1):204-12.

Boyne, P. and James, R.A. Grafting of the maxillary sinus floor with autogenous marrow and bone. Journal of Oral and Maxillofacial Surgery, (1980) 17, 113-116.

Cavalcanti MC at al. Maxillary sinus floor pneumatization and alveolar ridge resorption after tooth loss: a cross-sectional study. Braz Oral Rez. 2018 Aug 6 (32): 64.

Chanavaz, M. Sinus graft procedures and implant denrisry: a review of 21 years of surgical experience (1979-2000). Implant Dent. 9(3), 197-200.

Choucroun G. at al. Sinus Floor Cortication: Classification and Prevalence. Clin impland Dent Relat. 2017 Feb;19(1):6973.

Cruz RS at al. Short implants versus longer implants with maxillary sinus lift. A systematic review and meta-analysis. Braz Oral Rez. 2018;32:e86.

Daiane Balero Galindo at all. (2017). Main literary findings on autogenous and xenogenous grafting: A review. Dent Oral Craniofac Res, 4(3): 1-4.

Demircol M., Demircol N. (2019) The effects of posterior alveolar bone height on the height of maxillary sinus septa. Surg Radiol Anat. 2019 Sep;41(9):1003-1006.

Erhan Dursun at al. Maxillary sinus and surrounding bone anatomy with cone beam computed tomography after multiple teeth loss: a retrospective multicenter clinical study. Implant Dentistry. 2019 Jun;. 28, (3): 226-230.

Giovanni Felisati at al. Sinonasal complications resulting from dental treatment: Outcome-oriented proposal of classification and surgical protocol. Rhinol Allerg. 2013 Jul-Aug;27(4):e101-6.

Hoang JK at al. Multiplanar Sinus CT: A Systematic Approach to Imaging Before Functional Endoscopic Sinus Surgery. AJR Am J Roentgenol. 2010 Jun;194(6):W527-36.

Hoon Joo Yang, Soon Jung Hwang. Void space and long-term volumetric changes of maxillary sinus floor augmentation with comparison between hydroxyapatite soaked with bone morphogenetic protein 2 and anorganic bovine xenograft alone. CranioMaxillofac Surg. 2019 Oct; 47(10):1626-1632.

Horia Mihail Barbu at al. Management of Schneiderian Membrane Perforations during Sinus Augmentation Procedures: A Preliminary Comparison of Two Different Approaches. Clin Med. 2019 Sep 19;8(9).

Jensen OT at al. Report of the Sinus Consensus Conference of 1996. Oral Maxillofac Implants. 1998;13 Suppl:11-45.

Khalighi Sigaroudi A, Dalili Kajan Z, Rastgar S, Neshandar Asli H. Frequency of different maxillary sinus septal patterns found on cone-beam computed tomography and predicting the associated risk of sinus membrane perforation during sinus lifting. Imaging Sci Dent. 2017 Dec;47(4):261-7.

Kim H.J. at al. A retrospective study of implants placed following 1-stage or 2-stage maxillary sinus floor augmentation by the lateral window technique performed on residual bone of less than $4 \mathrm{~mm}$ : Results up to 10 years of follow-up. Periodontol. 2019 Aug 2.

Kim SM. Definition and management of odontogenic maxillary sinusitis. Maxillofac Plast Reconstr Surg. 2019 Mar 29;41(1):13.

Minhua Teng at al. Sinus Width Analysis and New Classification with Clinical Implications for Augmentation. Clin impland Dent Relat. 2016 Feb;18(1):89-96.

Niu L. at al. New classification of maxillary sinus contours and its relation to sinus floor elevation surgery. Clin impland Dent Relat. 2018 Aug;20(4):493-500.

Rapani M, Rapani C, Ricci L. Br. Schneider membrane thickness classification evaluated by cone-beam computed tomography and its importance in the predictability of perforation. Retrospective analysis of 200 patients. J Oral Maxillofac Surg. 2016 Dec. 54(10): 1106-1110. 
Rapani M. at al. Schneider membrane thickness classification evaluated by cone-beam computed tomography and its importance in the predictability of perforation. Retrospective analysis of 200 patients. Oal Maxillofac Surg. 2016 Dec;54(10):1106-1110.

Ritter A at al. Preoperative Maxillary Sinus Imaging and the Outcome of Sinus Floor Augmentation and Dental Implants in Asymptomatic Patients. Otol Rhinol Laryngol. 2019 Oct 21:3489419883292.

Sanz-Sánchez I et al. Effects of lateral bone augmentation procedures on peri- implant health or disease: A systematic review and meta- analysis. Clin Oral Impl Res. 2018; 29(15):18-21.

Sbordone C, Toti P, Guidetti F, Califano L, Pannone G, Sbordone L: Volumetric changes after sinus augmentation using blocks of autogenous iliac bone or freeze-dried allogeneic bone. A non-randomized study. J CranioMaxillofacial Surg 2014, 42:113-118.

Silva L.D. at al. Maxillary sinus lift surgery-with or without graft material? A systematic review. Oral Maxillofac Surg. 2016 Dec;45(12):1570-1576.

Smiler, D.G. \& Holmes, R.E. (1987) Sinus lift procedure usingporous hydroxyapatite: A preliminary clinical report. Journal of Oral Implantology13: 239-243.

Sonoda T. at al. Effect of Staged Crestal Maxillary Sinus Augmentation: A case series. Periodontol. 2019 Jul 31.

Stefano Corbella at al. Histomorphometric outcomes after lateral sinus floor elevation procedure: a systematic review of the literature and meta-analysis. 2016 Sep;27(9):1106-10.

Tatum, H. (1986) Maxillary and sinus implant reconstructions. Dental Clinics of North America 30: 207-210.

Torrade M., Marti C. Prevalence and management of Schneiderian membrane perforations during sinus-lift procedures. Clin. Oral Impl. Really. 19, 2008; 91-98 9

Yi-Wei Chen at al. A paradigm for evaluation and management of the maxillary sinus before dental implantation0 Laryngscope. 2018 Jun;128(6):1261-1265.

Zeng X. at al. Influence of Maxillary Sinus Width on Transcrestal Sinus Augmentation Outcomes: Radiographic Evaluation Based on Cone Beam CT. Clin impland Dent Relat. 2016 Apr;18(2):292-300. 


\title{
TOMOGRAPHIC EXAMINATION OF CHANGES IN MUCOPERIOST OF THE MAXILLARY SINUS AFTER SINUS LIFTING
}

\author{
Shpachynskyi Oleksandr \\ Dentist of Dental Medical Center of Bogomolets National Medical University, Ukraine \\ Skibitskyi Vadym
}

$\mathrm{PhD}$, associate professor Department of prosthetic dentistry Bogomolets National Medical University, Ukraine

\section{Filippenkova Larisa}

$\mathrm{PhD}$, associate professor Department of prosthodontics and orthodontics Kyiv Medical University, Ukraine

\section{Vasilevskyi Kostiyntin}

Doctor radiologist of Dental Medical Center of Bogomolets National Medical University, Ukraine

Didkovskyi Vyacheslav

$\mathrm{PhD}$, associate professor Department of otorhinolaryngology Bogomolets National Medical University, Ukraine

\section{Kopchak Andrii}

DM, Proffesor, Department of Dentistry of Postgraduate Education of Bogomolets National Medical University, Ukraine

Abstract. Restoration of the masticatory function in patients with edentulous posterior maxilla is often challenging due to the severe atrophy of the alveolar ridges and insufficient bone quantity for implant supported dentures. The purpose of this study was to analyze the change in mucoperiost after lateral sinus floor augmentation (LSFA) using cone beam computed tomography (CBCT).

LSFA procedures using different bovine bone materials with and withaut immediate implantation were performed at the Stomatological Medical Center of Bohomolets National Medical University in 87 patients, from 2016 to 2018. CBCT examination was performed before LSFA procedure in all patients, postoperative period: up to 1 month after surgery; and after 6 months, before implant placement or loading. Images were acquired using Planmeca ProMax 3D. Postoperative CBCT performed in early postsurgical period demonstrated that the number of case with type A decreased significantly from 86,67 to $26,75 \%$. The number of cases with type B radiological picture increased from $20,33 \%$ to $26,75 \%$. Mucoperiost type C was observed in 7,5 vs $41,73 \%$. Type D and E were observed in 13.91 and $2.14 \%$ However, the clinical signs of the acute sinusitis or specific complaints were recorded only in 2 cases. In 3 cases radiological findings resembled to $\mathrm{F}$ type. According to the results of the present study the minor radiologic changes in mucoperiost morphology were observed preoperatively in $17.12 \%$ of patients who underwent LSFA procedures. The incidence of sinusitis or graft failure in long term follow up consisted $19.26 \%$ while the frequency of asymptomatic radiological changes was significantly higher. It consisted 68.48 in early and $47.1 \%$ in late (6 months) postoperative period. As the differential diagnosis for such changes based only on clinical and radiological data is difficult, the obtained results prove the importance of preoperative endoscopic examination, intraoperative and postoperative control in patients with LSFA and the benefits of multidisciplinary approach of oral and ENT surgeons in asset of indications, ricks of the procedure, postoperative rehabilitation and complication management.

Key words: computed tomography, lateral sinus floor augmentation, mucoperiost, sinuslifting, sinusitis.

Manuscript is received 18.11.2019

Manuscripted is accepted 19.12.2019 